\title{
The self-concept of women with HIV and AIDS in Makassar
}

\author{
Ekawaty Hengki Utami ${ }^{1}$, Nurdiyanah Syarifuddin ${ }^{2}$, Muhammad Rusmin ${ }^{3}$ \\ 1,2,3 Bagian Promosi Kesehatan Universitas Islam Negeri Alauddin \\ 1,2,3 Bagian Administrasi Rumah Sakit Universitas Islam Negeri Alauddin
}

\begin{abstract}
Women infected with HIV and AIDS are mostly victims of their husbands' deviant behaviour. In that case, women with HIV and AIDS often suffer from psychological consequences that directly impact on their self-conception about their identities. This study employs phenomenological research method and selects its eight informants by snowball sampling technique. The informants consist of 6 women with HIV and AIDS, 1 counselling doctor, and 1 associate. The data were analysed with content analysis. The research findings suggest that most informants believe that they only gain knowledge about HIV and AIDS after they learn that they are infected by it through intervention programs. Prior to the intervention programs, they were not aware of the risks that the virus entails. The findings also report that the informants experience emotional turbulence after learning their condition even though it does not last long due to their realisation to their significant roles in the family as a mother and a wife. In addition to that, all informants sincerely hope for their recuperation, wish that their children do not carry the same virus in their bodies, and want to conceal the truth about their condition from the society. They are concerned of being rejected and discriminated by the society upon learning about the HIV and AIDS that they carry. All in all, psychological approach and counselling are significantly necessitated to help these women to maintain their positive self-conception.
\end{abstract}

Keyword: women; hiv; aids; self-concept

\begin{abstract}
ABSTRAK
Wanita dengan HIV dan AIDS cenderung menjadi korban atas perilaku menyimpang yang dilakukan oleh suaminya. Hal tersebut mejadi beban ganda serta memberi konsekuensi psikologis yang besar dan akan berdampak pada konsep diri wanita dengan HIV dan AIDS tersebut. Tujuan penelitian ini untuk mengetahui konsep diri wanita dengan HIV dan AIDS di Kota Makassar. Pendekatan penelitian ini adalah studi fenomenologi yang dipilih melalui snowball sampling terhadap 8 orang informan yang terdiri dari 6 orang wanita dengan HIV dan AIDS, 1 orang dokter konselor, dan 1 orang pendamping. Pengolahan data dilakukan dengan menggunkan content analysis. Hasil penelitian menunjukkan bahwa pengetahuan informan menjadi lebih baik mengenai penyakit HIV dan AIDS setelah mengetaui status karena adanya interfensi. Sebelum mengetahui status, informan tidak menyadari perilaku berisiko yang dilakukannya. Informan juga mengalami perubahan emosional, namun hal ini tidak berlangsung lama sebab para informan mengetahui kedudukannya sebagai ibu yang harus mengurus anak dan suami. Seluruh informan mengharapkan kesehatan dan kesembuhan kepada dirinya, mengharapkan agar anaknya tidak tertular, serta berharap agar statusnya tidak diketahui oleh lingkungan sosial. Informan memiliki ketakutan akan adanya tindak diskriminasi. Diperlukan pendekatan dan pendampingan lebih dari sisi psikologis agar wanita dengan HIV dan AIDS dapat memiliki konsep diri yang positif sehingga menjadi motivasi untuk tetap bertahan.
\end{abstract}

Kata kunci: wanita; hiv; aids; konsep diri

\section{PENDAHULUAN}

Di seluruh dunia, pada tahun 2013 terdapat 35 juta orang yang dinyatakan hidup dengan HIV, meningkat sekitar 1 juta orang dari data sebelumnya yakni sekitar 34 juta orang pada tahun 2010. Dari 35 juta orang tersebut, terdapat 16 juta peremp uan. Selain itu, jumlah kematian akibat AIDS dilaporkan sebanyak 1,5 juta orang yang terdiri dari 1,3 juta orang dewasa dan 190.000 anak yang berusia $<15$ tahun (Pusat Data Dan Informasi Kementrian
Alamat Korespondensi:

Gedung FKIK Lt.1 UIN Alauddin Makassar

Email: ekawatyhengki@gmail.com
ISSN-P : 2086-2040

ISSN-E : 2548-5334

Volume 12, Nomor 1, Januari-Juni 2020 
Kesehatan, 2014) .

Data Kementrian Kesehatan RI, menunjukkan bahwa kasus HIV di Indonesia mengalami penurunan dari 29.037 kasus pada 2013 menjadi 22.869 kasus pada 2014. Sama halnya dengan kasus AIDS yang pada tahun 2013 terdapat 6.266 kasus turun menjadi 1.876 kasus pada 2014. Jika ditinjau dari segi jenis kelamin, pada tahun 2014 terdapat 13.280 infeksi HIV oleh laki-laki dan 9.589 infeksi pada perempuan. Faktor risiko tertinggi hingga tahun 2014 masih pada hubungan heteroseksual dengan kisaran 8,922 (Pusat Data Dan Informasi Kementrian Kesehatan, 2014).

Pada provinsi Sulawesi Selatan, terjadi peningkatan angka kejadian HIV dan AIDS yakni pada tahun 2010 sebanyak 607 orang dengan HIV dan 650 orang dengan AIDS meningkat di tahun 2013 menjadi 844 orang dengan HIV namun menurun pada penderita AIDS menjadi 328 orang. Angka kejadian HIV kembali meningkat di tahun 2016 menjadi 1.030 orang terjangkit HIV dan 578 orang dengan AIDS. Ibu kota Provinsi Sulawesi Selatan menduduki peringkat pertama dengan angka kejadian HIV dan AIDS dari tahun ke tahun. Pada tahun 2011 kejadian HIV sebanyak 528 orang dan 461 orang dengan AIDS. Kejadian HIV meningkat di tahun 2015 menjadi 665 orang sementara penderita AIDS menurun menjadi 208 orang. Pada tahun 2016, penderita
HIV kembali meningkat menjadi 773 orang dan penderita AIDS menjadi dua kali lipat dari tahun sebelumnya yaitu 432 penderita Wanita dengan HIV dan AIDS mengalami berbagai permasalahan baik masalah fisik, psikososial, emosional maupun spiritual. Masalah fisik yang terjadi pada wanita dengan HIV dan AIDS akibat penurunan daya tahan tubuh yang mengakibatkan wanita tersebut rentan terhadap berbagai penyakit infeksi. Selain masalah fisik, wanita dengan HIV dan AIDS juga mengalami masalah sosial antara lain dikucilkan oleh teman, keluarga maupun masyarakat. Hal ini yang dianggap dapat mempengaruhi konsep diri pada wanita tersebut (Indriastuti, 2015).

Konsep diri dapat berpengaruh pada kepribadian dalam diri dan bisa mempengaruhi bagaimana seseorang menyikapi sebuah permasalahan. Hal ini yang menjadi dasar peneliti tertarik untuk melakukan penelitian mengenai Konsep Diri Wanita Dengan HIV dan AIDS di Kota Makassar

\section{METODE PENELITIAN}

Penelitian ini merupakan penelitian kualitatif dengan pendekatan fenomenologi. Informan dipilih dengan metode Snowball Sampling. Pengumpulan data dilakukan melalui wawancara langsung secara mendalam (Indepth Interview) terhadap informan yaitu 
berupa dialog secara individu dengan menggunakan pedoman wawancara (Interview Guide) dan diperoleh 8 orang informan. Hasil penelitian dianalisis dengan menggunakana konten analisis.

\section{HASIL PENELITIAN}

Karakter informan sebelum didiagnosa atau menderita HIV dan AIDS kurang lebih tidak jauh berbeda untuk masingmasing informan. Serta sebagian besar informan mengatakan bahwa mereka tidak merasakan adanya perbedaan yang signifikan terhadap karakternya.

Selain bersifat sabar, ada pula informan yang merupakan pendamping mengatakan jika wanita dengan HIV dan AIDS akan lebih sensitif dalam menanggapi sesuatu. Hal ini disebabkan karena kejiwaan mereka yang mulai terganggu setelah mengetahui status sebagai penderita HIV dan AIDS.

Namun setelah mengikuti beberapa pelatihan dan bertemu dengan lebih banyak lagi penderita, informan lambat laun mulai menerima dirinya sendiri dan tidak terlalu memikirkan penyakitnya. Hal ini juga disebabkan karena informan memikirkan kelangsungan hidup anaknya.

"Pasien itu agak sensi karena mere$k a$ kejiwaannya sudah terganggu setelah kepikiran dengan minum obat seumur hidup, beban itu yang menjadi patokan utama, kan.” (YL, 34
Tahun, Pendamping, Agustus 2017).

"Pertamanya pasti, sampai satu minggu menangis-menangis. Tapi lama-lama saya pikir, kalau saya tambah stress nanti saya tambah ini, tambah parah. Sementara saya orang hamil." (HR, 32 tahun, Wiraswasta, Agustus 2017)

Sebelum mengetahui status sebagai penderita HIV dan AIDS, pada umumnya informan tidak menyadari bahwa dirinya termasuk dalam kelompok berisiko. Hal ini dapat dilihat dari perilaku berhubungan seksual yang tidak aman, sementara keseluruhan informan mendapatkan jangkitan virus dari suami.

Selain informasi mengenai perilaku berisiko yang tidak disadari oleh informan, ada pula informasi mengenai pengetahuan informan mengenai perilaku mereka terhadap lingkungan sosial.

Secara keseluruhan, hampir semua informan mengatakan bahwa mereka merasakan adanya perubahan pada perilaku mereka setelah mengetahui status sebagai penderita HIV dan AIDS. Namun sebagian besar informan mengatakan bahwa perilaku mereka setelah mengatahui status, lebih mengarah pada perilaku kesehatan yang membaik mengingat kondisi mereka yang semakin rentan terhadap beberapa penyakit.

"Saya kan tau pada saat periksa kehamilan anakku yang kedua ini dan dokter bilang saya positif. Yah pasti 
dari suamiku yang pertama, saya tidak tau juga kalau ternyata dia ada ini jadi saya tidak lakukan apa-apa." ( $\mathrm{H}$, 33 Tahun, Pedagang, Juli 2017).

"Seperti biasa sih. Tidak terlalu bagaimana, palingan kalau yang dulu agak cuek sama kesehatan atau kebersihan, cuma itu mungkin." (HR, 32 Tahun, Wiraswasta, Agustus 2017).

Pengetahun informan mengenai kedudukan mereka dalam keluarga yakni mereka merupakan seorang ibu yang harus mengurus anak dan suaminya. Ada juga salah satu informan yang mengatakan bahwa ia hanya mengurus dirinya saja dan anaknya sebab tidak lagi bersama dengan suaminya.

Selain sebagai ibu dan istri, informan juga mengatakan bahwa dia sebagai menantu juga seringkali membantu mertua berjualan, serta sebagai anak juga masih bisa mengurus orang tua dengan baik.

"Di rumah tangga, Ahlamdulillah saya masih bisa mengurus anak, mengurus suami, bisa rumah tangga bahkan bisa melahirkan ju a kan. Orang tuau juga masih bisa saya urus." (AY, 34 Tahun, Konselor, Juli 2017).

Dalam lingkungan sosial, setiap individu juga memiliki kedudukan yang berbeda-beda. Mulai dari sebagai warga biasa atau teman biasa hingga ada yang dianggap sebagai orang yang berpengaruh dalam lingkungannya. Sama halnya dengan informasi yang ingin diketahui dari para informan dalam penelitian ini

"Di lingkungannya mertuaku juga almarhun, almarhum suamiku juga sudah tau semua. Kan mertuaku juga dulu lurah jadi dia tau semua wargawarganya. Begini jiga caraku menjelaskan tentang HIV. (AY, 34 Tahun, Konselor, Juli 2017).

Informan AY juga menambahkan bahwa ia menjadikan hal itu sebagai peluang baginya untuk menjelaskan mengenai HIV dan AIDS. Begitupun di lingkungan tempat tinggal informan sendiri.

“... Kalau di sinikan rata-rata sepupuku, kapan ada ngumpulngumpul anak muda ke situ ka. Terbantuki, maksudanya mereka bantuka juga untuk jangkau juga temanteman, jadi mereka tau saya di LSM HIV." (AY, 34 Tahun, Konselor, Juli 2017).

Secara umum, pengetahuan informan mengenai penyakit HIV dan AIDS sebelum mereka mengetahui status sebagi penderita HIV dan AIDS terbatas hanya sampai mengetahui bahwa memang ada penyakit yang demikian. Penyakit tersebut merupakan penyakit yang menular dan penularan penyakit melalui seks bebas dan penggunaan jarum suntuk secara bergantian.

Setelah informan mendapatkan dampingan oleh pendamping dan dokter, pengetahuannya mengenai penyakit HIV dan AIDS menjadi bertambah. Informan telah mengetahui cara dan media penularan dari penyakit HIV dan AIDS. Informan juga telah mengetahui cara untuk mempertahankan kesehatnnya dengan mengatur pola makan. 
"Setelahnya kan kita didampingi sama pendamping, jadi mulai lah bertambah pengetahuan. Kayak harus mungikin atur pola makan kita sudah tau juga bilang ini menular lewat apa saja.” (H, 33 Tahun, Pedagang, Juli 2017).

Dari sudut pandang pendamping, hal yang sama mengenai pengetahuan yang membaik juga dirasakan dengan jelas. Namun yang dititik beratkan pada pendamping adalah bagaimana cara pasien atau penderita HIV dan AIDS dapat membawa dirinya. Dalam hal ini adalah bagaimana penderita dapat menyesuaikan diri dengan statusnya sendiri sebagai pendiri, bagaiman cara penderita menjelasakan dan meneriam berbagai macam pandanagan dari orangorang di sekitarnya.

Keseluruhan informan mengatakan bahwa harapan mereka untuk dirinya sendiri adalah mendapatkan kesembuhan atau sehat.

"Mudah-mudahan sehat terus, biarpun itu minum obat asal apa namanya, semoga sehat terus." ( $\mathrm{H}, 33 \mathrm{Ta}-$ hun, Pedagang, Agustus 2017).

“ ... Tapi paling utama itu saya bisa bertahan hidup dulu. Bertahan hidup paling tidak sehat. Patuh sama obat, paling tidak sampai yah kalau bisa sampai bisa ditemukan obat pembunuh virusnya ..." (AY, 34 Tahun, Konselor, Juli 2017).

Harapan untuk keluarga, informan dalam penelitian ini adalah agar anak-anak mereka tidak ada yang tertular oleh penyakit HIV dan AIDS. Selain menjaga kesehatan pribadi, informan menjadi lebih protektif kepada anak dan suami yang tidak menderita penyakit yang sama.

"Cuma itu saja, saya fokus sekarang di anak. Bagaimana anak supaya tidak kena, itu saja. Kalau saya tidak terlalu pusing, tinggal anak. Yang jelas ku pikir, saya biasa bicara sama suami, yang jelas kita harus hidup samapi 20 tahun ke depan. Minimal ini anak sudah bisa mandiri. Itu saja, itu saja prinsipku berdua. Sudah." (HR, 32 Tahun, Wiraswasta, Agustus 2017)

Harapan informan terhadap lingkungan sosial adalah agar status mereka tidak diketahui oleh masyarakat sekitar. Informan merasa cukup dengan mendapat dukungan dari keluarga. Bagi informan yang telah diketahui statusnya oleh masyarakat, memiliki harapan agar mendapatkan penerimaan yang baik dan dukungan atas penyakit yang dideritanya.

"Jangan sampai orang lainnya tau karena kan ini, kita juga tidak tau bagaimana orang." (EV, 33 Tahun, IRT, Agustus 2017).

"Pasti mereka berharap supaya diterima di lingkungannya, tidak dikucilkan, begitu." (dr. E, 42 Tahun, Dokter/Konselor, Agustus 2017).

Pada penelitian ini, informan memilih pasrah akan penyakit HIV dan AIDS yang dideritanya dan menjalani hidup sebgaimana mestinya. Namun ada pula informan 
yang merasakan adanya perubahan yang baik terhadap dirinya setelah mengetahui status.

"Pasrah saja orang, mau diapa lagi karena bukan mauku juga, kita tidak tau. Kita ini kasihan cuma terjangkit juga." H, 33 Tahun, Pedagang, Juli 2017).

"Kalau dibilang penilaian, saya lebih senang dengan diriku yang sekarang . karena saya lebih bisa bersosialisasi." (AY, 34 Tahun, Konselor, Juli 2017).

Informan yang mendapatkan penerimaan yang baik terhadap kelaurga merasa sangat bersyukur. Namun ada pula informan yang memilih untuk tidak membuka statusnya bahkan kepada anggota keluarga sendiri.

"Alhamdulillah karena keluarga tau, sekalipun tidak semua. Mereka jugalah yang dukungka itu kasihan." (L, 34 tahun, IRT, Agustus 2017).

"Tidak ku kasih tau. Karena saya pikir tidak perlu juga. Karena saya sudah tanyakan dokter apakah memang menular sama anak ataukah apa, dia bilang tidak. Kecuali kalau suami memang ini (berhubungan seks), tapi saya juga sudah putus ini, kan." (HM, 48 Tahun, IRT, Agustus 2017).

Lingkungan sosial tidak serta merta memahami keadaan penderita HIV dan AIDS. Beberapa dari informan sempat mendapatkan diskriminasi dari lingkungan sosial. Sekalipun pada akhirnya lingkungan dapat memahami keadaan penderita.

"Saya memang sempat dapat diskriminasi dari lingkungan, tapi saya jelaskan ke mereka baik-baik. Dan Alhamdulillah mereka bisa menerima." (AY, 34 Tahun, Konselor, Juli 2017).

"Seperti mungkin ketika dia tau statusnya, misalkan tetangga ada yang tau statusnya kadang perlakuan mereka beda. Tapi kita damping mereka, kasih tau bahwa tidak perlu ditanggapi yang seperti itu. Yah teman-teman juga akhirnya cuek saja sama tanggapan yang seperti itu.” (YL, 34 Tahun, Pendamping, Agustus 2017).

Informan dalam penelitian ini megatakan bahwa penyakit HIV dan AIDS yang kini dideritanya merupakan ketentuan Yang Maha Kuasa. Kedua informan memilih untuk pasarah dan menjalinya saja.

"Apa boleh buat, itu sudah ketentuannya Tuhan, begitu. Saya tidak tau, yah. Malah saya lebih sadari diriku sendiri. Saya salahkan diriku sendiri, tidak mungkin penyakit ini datang, pasti salahku sendiri, kan." (HM, 48 Tahun, IRT, Agustus 2017).

\section{PEMBAHASAN}

Reaksi yang pertama muncul setelah penderita didiagnosa terinfeksi HIV adalah kaget, tidak percaya, gusar, kemudian setelah timbul beberapa gejala terminal, orang dengan HIV dan AIDS akan menjadi mati rasa, frustasi, sedih, dan depresi menurut hasil penelitian oleh Rohmat (2011). Hal serupa juga ditemukan dalam penelitian ini, di mana para informan 
mengatakan bahwa mereka kaget setelah mengetahi bahwa dirinya positif terinfeksi HIV. Ada informan yang bahkan mengatakan bahwa dia merasa ingin bunuh diri akibat depresi. Ada pula informan yang meminta bidan untuk menggugurkan kandungannya sebab pada saat itu dia dalam kondisi hamil.

Jika ditinjau dari lama jangkitan, seorang informan yang telah terjangkit selama 10 tahun saat ini telah menjadi seorang konselor. Hal ini disebabkan karena adanya rasa ingin meguatkan antara satu sama lain dengan para penderita. Selain itu, informan juga mengatakan bahwa ia ingin menyingkirkan stigma masyarakat terhadap penderita HIV dan AIDS yang selama ini beranggapan negatif dan melakukan tindak diskriminasi.

Sebagian besar infoman yang merupakan wanita dengan HIV dan AIDS dapat menjelaskan beberapa hal yang mereka ketahui pada dirinya yang berkaitan dengan karakter mereka masing-masing. Wanita dengan HIV dan AIDS yang merupakan informan utama, mengatakan bahwa karakter yang mereka ketahui pada dirinya adalah mereka merupakan pribadi yang sabar. Beberapa informan hanya dapat mengatakan bahwa dia merupakan peribadi yang sabar. Adapun informan yang mengatakan bahwa dalam menanggapi sebuah persoalan, informan memilih untuk tidak mengambil pusing atau membesarbesarkan persoalan tersebut.

Di sisi lain ada pula informan yang mengatakan bahwa dia merupakan pribadi yang tertutup sebelum mengetahui status dan justru menjadi pribadi yang lebih terbuka serta mudah bersosialisasi setelah mengetahui status sebagai penderita HIV dan AIDS. Chandra, dkk (2012) menuliskan dalam penelitiannya bahwa beberapa penderita HIV dan AIDS ada yang sangat terbuka mengenai status HIV mereka dan bersedia menjadi narasumber pada berbagai acara seminar dan penyuluhan mengenai HIV.

Informan dalam penelitian ini tanpa menyadari diri mereka masing-masing berada dalam perilaku berisiko saat berhubungan suami istri. Semua informan baru mengetahui bahwa suami mereka menderta HIV dan AIDS saat suaminya telah dirawat di rumah sakit atau saat informan memeriksakan kehamilan. Meskipun demikian, informan sebenarnya telah mengetahui bahwa sebelum menderita HIV dan AIDS, suami mereka telah melakukan hal-hal yang melanggar norma seperti menggunakan narkoba. Namun, para informan tidak dapat berbuat banyak sebab pengetahuan mereka yang rendah dan status sebagai istri yang harus mematuhi suami.

Tidak jauh berbeda dengan penelitian dari negara Malaysia oleh Muda \& Aziz 
(2015) mengatakan bahwa wanita yang terjangkit HIV dan AIDS cenderung memiliki pengalaman yang lebih buruk dibandingkan dengan pria. Hal ini dikarenakan wanita hanya memiliki sedikit bahkan tidak ada kemampuan untuk membuat keputusan terutama dalam memilih pasangan hidup, menentukan cara berhubungan seks, mendapatkan perawatan, sumber informasi, serta hak untuk mengetahui latar belakang laki-laki yang akan dinikahinya. Dilanjutkan bahwa bahkan dalam hal berhubungan seks, wanita juga kurang berupaya membebaskan diri dari jangkitan HIV dan AIDS melalui hubungan seks yang aman, seperti penggunaan alat kontasepsi.

Sebelum mengetahui status, beberapa informan mengatakan bahwa kepeduliannya terhadap kesehatan masih kurang. Sementara setelah mereka mengetahui status, mereka menjadi lebih peka terhadap kesehatan diri sendiri maupun kepada anak atau suaminya.

Kedudukan Informan Dalam Keluarga

Seluruh informan menjelaskan bahwa dalam keluarga, mereka berperan sebagai ibu yang kesehariannya adalah mengurus anak-anak mereka. Selain itu, informan juga mengatakan bahwa mereka juga masingmasing dapat berperan baik sebagai istri dengan masih mengurusi suami mereka bagi yang memiliki suami. Ada pula informan yang merasa masih sanggup untuk mengu- rus orang tuanya, tanpa harus memperdulikan statusnya sebagai penderita HIV dan AIDS.

Hadi Pranata dalam Handayani, 2003 mengatakan bahwa komponen dalam proses pembentukan konsep diri antara lain adalah Family Self yang merupakan bayangan kebanggaan seseorang terhadap citra ayah, ibu, dan sanak saudara. Ini menggambarkan persepsi diri individu dalam kaitannya dengan kelompok primer seperti keluarga dan teman-teman dekatnya (Widiaji, 2015).

Dalam lingkungan sosial, beberapa informan mengatakan bahwa mereka bersosialisasi kepada orang-orang sekitar seperti biasa. Informan tersebut merasa bahwa tidak ada peran penting bagi dirinya terhadap lingkungan. Mereka hanya orang atau warga biasa yang dalam kesehariannya terkadang bersosialisasi dengan masyarakat di sekitar tempat tinggal jika dianggap perlu dan seadanya saja.

Namun ada pula salah satu informan yang mengatakan bahwa statusnya sebagai konselor dalam sebuah Lembaga Swadaya Masyarakat (LSM) HIV dan AIDS telah diketahui oleh masyarakat sekitar tempat tinggalnya. Hal ini menjadi kesempatan yang baik bagi informan untuk berbagi informasi dan memberikan pengertian kepada masyarakat sekitar mengenai penyakit HIV dan AIDS.

Hadi Pranata dalam Handayani (2003) 
melanjutkan komponen dalam pembentukan konsep diri juga adalah Social Self, yang merupakan bayangan sesorang terhadap kelompok sosialnya di manapun orang tersebut berada terkait dengan komitmennya. Hal ini menggambarkan diri individu dalam kaitannya dengan interaksi sosialnya dengan orang lain.

Pada penelitian ini, diperoleh informasi dari wanita dengan HIV dan AIDS mengenai pengetahuan mereka tentang penyakit HIV dan AIDS sebelum dan setelah mereka mengetahui status. Sebelumnya, keseluruhan informan mengatakan bahwa pengetahuan mereka mengenai penyakit HIV dan AIDS terbatas hanya pada tingkat tahu bahwa penyakit HIV dan AIDS adalah penyakit menular dan penularan penyakit dapat terjadi melalui hubungan seksual.

Namun setelah mengetahui status sebagai penderita HIV dan AIDS, wanitawanita ini mengatakan bahwa mereka dapat merasakan adanya peningkatan pengetahuan mereka mengenai HIV dan AIDS. Peningkatan pengetahuan ini diperoleh dari beberapa informasi dari dokter di layanan masing-masing saat menjalani konseling serta dari beberapa pertemuan atau pelatihan dari LSM terkait.

Hal ini sejalan dengan hasil penelitian oleh Lestari (2015) yang menunjukkan bahwa pengetahuan ibu rumah tangga sebe- lum diberikan sosialisasi dengan kategori pengetahuan rendah yaitu sebanyak 16 responden $(69,3 \%)$, sedang sebanyak 9 responden $(33,3 \%)$ dan tinggi sebanyak 2 reponden $(7,4 \%)$. Pengetahuan ibu rumah tangga sesudah diberikan sosialisasi dengan kategori rendah sebanyak 4 responden $(25,9 \%)$, sedang sebanyak 9 responden $(33,3 \%)$ dan tinggi sebanyak 11 responden $(40,7 \%)$.

Secara umum, harapan wanita Dengan HIV dan AIDS untuk dirinya adalah agar mereka dapat terus dalam keadaan yang sehat atau dengan kata lain dapat mempertahankan derajat kesehatannya. Hasil penelitian ini didukung oleh penelitian dari Safitri (2015) yang mengatakan bahwa wanita dengan HIV dan AIDS memiliki keinginan kuat untuk tetap sehat dan dapat melakukan kegiatan sehari-hari, hal ini menjadi motivasi untuk diri sendiri pada wanita dengan HIV dan AIDS.

Selain harapan untuk sehat, lebih jauh lagi wanita dengan HIV dan AIDS ingin sembuh secara total dari penyakit yang dideritanya. Hal ini juga kembali dipertegas dalam penelitian oleh Safitri (2015) yang mengataan bahwa wanita dengan HIV dan AIDS meskipun mengalami keterpurukan saat didiagnosa HIV positif, namun mereka tetap memiliki harapan untuk dirinya sendiri serta lingkungan sekitarnya. Harapan untuk diri sendiri ada obat yang dapat 
menyembuhkan serta ingin sembuh dari penyakit.

Harapan Informan Terhadap Keluarga

Seluruh informan utama yakni wanita dengan HIV dan AIDS telah memiliki anak. Informan yang pada dasarnya merupakan ibu, berharap besar agar anaknya tidak sampai tertular oleh penyakit yang sedang dideritanya. Informan mengatakan bahwa saat ini fokus utama mereka adalah mengurus anak sebaik mungkin agar informan dapat melihat setiap perkembangan pada anaknya.

Hal serupa ditemukan dalam penelitian oleh Indriastuti (2015). Dalam penelitian Indriastuti tersebut dijelaskan bahwa partisipan dalam penelitiannya mempunyai komitmen yang bagus terhadap anaknya yaitu pada saat hamil dengan mempertahankan kehamilannya dan menjaga menjaga kehamilannya tetap sehat, melahirkan dan berupaya untuk merawat anaknya dengan baik meskipun partisipan mempunyai status HIV positif namun partisipan tetap berkomitmen untuk bisa merawat anaknya dengan baik sama seperti ibu-ibu lain yang tidak menderita HIV.

Harapan terhadap lingkungan oleh salah satu informan dalam penelitian ini mengatakan bahwa sebenarnya yang mereka butuhkan adalah perhatian. Perhatian yang dimaksudkan adalah orang-orang sekitar dapat memahami penyakit yang sedang diderita oleh informan, orang-orang sekitar dalam memberikan kepedulian, serta dapat merangkul dan memberikan semangat kepada informan.

Hasil penelitian ini berkaitan dengan hasil penelitian oleh Widiaji (2015). Berdasarkan hasil penelitian oleh peneliti tersebut, ditemukan bahwa informannya mengharapkan agar masyarakat tidak memberikan stigma negatif kepada penderita HIV dan AIDS, serta agar penderita HIV dan AIDS tidak didiskriminasi oleh masyarakat tetapi justru lebih memberikan perlakuan positif, seperti diperhatikan dan disayangi.

Penerimaan akan status HIV membuat ODHA lebih tenang dan realistis dalam menghadapi kondisinya. Ia akan mencari jalan keluar atas permasalahannya dengan cara mencari informasi dan layanan kesehatan, Silitonga (2013). Sejalan dengan penelitian yang dilakukan oleh Silitonga, dalam penelitian ini beberapa informan juga mengatakan pasrah dengan keadaan yang dihadapi saat ini.

Apabila seseorang ditimpa musibah, seperti halnya yang dialamai oleh informan, sesungguhnya sebagai manusia bisa kita tidak dapat melakukan penolakan atas musibah tersebut. Oleh sebeb itu, sudah sepantasnya informan berlapang dada dan menerima hal tersbut dengan penuh kesabaran. Seperti potongan ayat yang disebutkan dalam Q.S Az-Zumar ayat 10, yang ter- 
jemahnya:

\section{“... Sesungguhnya hanya orang- orang yang bersabarlah yang dicukupkan pahala mereka tanpa ba- tas." \\ Dalam tafsil Al-Ahzar dijelaskan} bahwa terjemah pada ujung ayat surah AzZumar tersebut berbunyi, "Sesungguhnya hanya orang-orag yang bersabarlah yang dicukupkan pahala mereka tanpa batas." Pada ujung ayat ini pula sudah diisyaraktan bahwa beriman, mengisi hidup dengan takwa dan berbuat kebajikan tidaklah semudah apa yang kita kira. Allah akan memberikan kita cobaan dengan alat utama untuk menangkis cobaan tersebut adalah dengan kesabaran. Hanya orang-orang sabarlah yang akan sampai kepada apa yang dituju, yaitu pahala yang berlipat-lipat ganda di sisi Allah.

Pada umumnya, informan pada penelitian ini hanya membuka statusnya pada keluarga inti, seperti suami. Beberapa informan yang melakukan hal tesebut beranggapan bahwa dukungan dari keluarga intilah yang terpenting. Seperti halnya dalam penelitian Indriastuti (2015). Pada penelitian tersebut dikatakan bahwa wanita yang mendapatkan dukungan baik dari suami, keluarga maupun masyarakat akan memperoleh support system yang baik dan merupakan hal yang penting bagi ibu untuk menjalankan perannya sebagai ibu.
Dukungan suami, keluarga dan masyarakat menjadi sangat penting karena mempunyai kontribusi pada pencapaian peran ibu.

Ada pula informan yang memilih untuk menutup total statusnya bahkan kepada suami dan anaknya. Selain itu ada pula informan yang menutup status dari kelaurga besar seperti kepada orangtua atau sanak saudara. Informan merasa hal tersbut tidaklah penting untuk diberitahukan. Setelah dikaji lebih mendalam, informan ternyata meraa takut jika mendapatkan diskriminasi. Hal ini sejalan dengan penelitian yang dilakukan oleh Chandra, dkk (2012). Keluarga responden pada umumnya mengetahui status HIV responden, namun beberapa hanya diketahui oleh keluarga inti dengan alasan bahwa keluarga yang lain tidak perlu mengetahui status mereka dan mencegah menjadi bahan pembicaraan orang lain.

Safitri (2015) menyatakan bahwa dengan adanya dukungan sosial maka akan tercipta lingkungan yang kondusif sehingga memberikan motivasi dan wawasan baru bagi penderita HIV dan AIDS. Dalam penelitian yang dilakukan Safitri tersebut, dukungan yang diterima yaitu dukungan dari keluarga, dukungan teman pendamping ODHA serta dukungan dari tenaga kesehatan. Dukungan tersebut sangat berpengaruh bagi wanita dengan HIV dan AIDS untuk tetap menjalankan pengobatan, karena pengobatan yang dilalui oleh para 
wanita dengan HIV dan AIDS selama seumur hidup.

Jika dibandingkan dengan penelitian Safitri di atas, dalam penelitian ini memang ada beberapa informan yang dapat merasakan langsung dukungan sosial yang baik sekalipun sebelumnya mendapatkan diskriminas. Namun, sebagian informan memilih untuk menutup status mereka dari lingkungan sosial. Wanita dengan HIV dan AIDS merasa bahwa membuka status kepada lingkungan sosial tidak akan berdampak banyak kepada dirinya. Kembali lagi, ketakutan akan diskriminasi, penolakan, atau sindiran yang menghantui pikiran informan sehingga merasa tidak perlu untuk membuka status pada lingkungan sosial. Ketakutan akan penolakan juga ditemukan dalam penelitian Orza, dkk (2015) yang sekitar $78 \%$ respondennya pernah mengalami penolakan sehingga membuatnya berada dalam rasa takut dan memilih untuk merahasiakan statusnya walapupun hanya dengan sedikit dukungan yang baik.

Penilaian Informan Secara Moral Spiritual

Sebagian besar informan menganggap penyakit HIV dan AIDS sebagai rejeki yang dipercayakan kepadanya. Informan mengaku pasrah dan memilih untuk menjalinya saja. Bahkan mereka berusaha untuk mengintrospeksi diri masing-masing dan berusaha untuk mendekatkan diri kepada
Allah swt. dengan memperbaiki idadah masing-masing. Seperti halnya yang dikatakan Hidayanti (2012) bahwa secara umum penderita HIV dan AIDS menjadi orang yang lebih religius setelah terinfeksi HIV dan AIDS. Keinginan untuk bertaubat mendorong dirinya untuk mendekatkan diri pada Tuhan. Ritual dan ibadah yang dilakukannya sebagai bentuk permohanan ampun kepada Tuhan atas segala kesalahan masa lalu.

\section{KESIMPULAN}

Berdasarkan hasil penelitian yang dilakukan mengenai Konsepp Diri Wanita Dengan HIV dan AIDS di Kota Makassar, maka diperoleh kesimpulan sebagai berikut: (1) Secara umum, pengetahuan informan menjadi lebih baik setelah mengetahui status sebagai penderita. Walapun pada awal diagnosa, informan mengalami depresi namun hal tidak berlangsung lama. Adanya dampingan dan intervensi dari petugas kesehatan dan pendamping membuat informan menjadi lebih bisa menerima keadaan. (2) Sebagian besar informan memiliki harapan untuk sehat dan sembuh bagi dirinya sendiri. Berharap agar anaknya tidak terjangkit penyakit HIV dan AIDS, serta berharap agar statusnya tidak diketahui oleh orang yang lebih banyak karena adanya ketakutan menerima diskriminasi. (3) Keseluruhan informan memilih untuk pasrah dan 
menerima keadaan sebagai penderita HIV dan AIDS. Bersyukur terhadap penerimaan keluarga yang juga dijadikan sebagai motivasi, serta menutup status dari lingkungan sosial karena dianggap tidak perlu. informan juga merasakan adanya peningkatan frekuensi beribadah serta menganggap penyakit HIV dan AIDS yang diderita sebagai rejeki ataupun cobaan dari Yang Maha Kuasa.

\section{SARAN}

Berdasarkan penelitian yang telah dilakukan dan dengan segala keterbatasan serta kekurangan, maka peneliti mengajukan saran sebagai berikut: (1) Informan semoga dapat lebih mengenali diri sendiri agar dapat memperoleh konsep diri yang lebih positif sehingga memiliki motivasi yang kuat untuk terus bertahan hidup serta lebih mendekatkan diri kepada Allah swt. (2) Kepada masyarakat umum atau yang memiliki anggota keluarga yang menderita HIV dan AIDS agar memberikan dukungan mental, tidak melakukan tindak diskriminasi. (3) Kepada petugas kesehatan, kelompok dukungan sebaya, LSM dan sejajaran untuk dapat lebih memberikan edukasi serta dukungan kepada penderita HIV dan AIDS mengenai kepatuhan berobat, penerimaan terhadap diri mereka, serta sikap dalam menanggapi opini masyarakat umum. (4) Bagi peneliti selanjutnya agar dapat mengkaji lebih dalam dan melihat faktor-faktor yang lain sehingga dapat dibandingkan dengan penelitian ini dan diperoleh hasil yang lebih fariatif. (5) Bagi peneliti sendiri agar dapat menjadikan penelitian ini sebagai pembelajaran hidup dan lebih bersyukur serta menerima segala sesuatu yang Allah karuniakan.

\section{DAFTAR PUSTAKA}

Chandra, A. S., Sugiarto, C., Jonathan, R., Kedokteran, F., Maranatha, U. K., Prof, J., Suria, D., Mph, S., \& Bandung, N. (2012). GAMBARAN PENULARAN DAN STIGMA PADA PEREMPUAN DENGAN Human Immunodeficiency Virus / Acquired Immune Deficiency Syndrome DI Klinik Swasta Khusus Kota Bandung Description Of Transmission And Stigma In Women Living With Hiv / Aids At Private Clinic Bandung. 7.

Hidayanti, E. (2012). Dimensi PsikoSpiritual Dalam Praktik Konseling Bagi Penderita Hiv/Aids Di Klinik Voluntary Counselling Test (VCT) rumah sakit panti wiloso citarum semarang. 82 .

Indriastuti, N. A. (2015). Faktor-faktor yang Mempengaruhi Pencapaian Peran sebagai Ibu pada Perempuan dengan HIV / AIDS di Yogyakarta Factors that Affect Maternal Role Attainment in Women with HIV / AIDS in Yogyakarta. 15(1), 75-83.

Lestari, E. (2015). Perbedaan pengetahuan ibu rumah tangga sebelum dan sesudah diberi sosialisasi pencegahan hiv/aids di desa tleter kecamatan kaloran kabupaten temanggung. 13. 
Muda, M., \& Aziz, R. A. (2015). Wanita dan HIV / AIDS di Malaysia: Punca jangkitan dari aspek sosiobudaya Women and HIV / AIDS in Malaysia : Socio-cultural causes of infection. 1 (1), 73-86.

Orza, L., Bewley, S., Logie, C. H., Crone, E. T., Moroz, S., Strachan, S., Vazquez, M., \& Welbourn, A. (2015). How does living with HIV impact on women's mental health? Voices from a global survey. 18(Suppl 5), 19.

Pusat Data Dan Informasi Kementrian Kesehatan. (2014). Infodatin AIDS (pp. 1-8).
Rohmat, M. S. (2011). Gambaran konsep diri pada orang dengan hiv / aids di rumah sakit grhasia provinsi daerah istimewa program studi ilmu keperawatan sekolah tinggi ilmu kesehatan ' aisyiyah yogyakarta gambaran konsep diri pada orang dengan hiv / aids di rumah sakit grhasia.

Safitri, A. (2015). Pengalaman perempuan dengan hiv/aids dalam menjalani pengobatan. 2(2), 9 .

Silitonga, h. T. H. (2013). Konsep Diri Orang Dengan Hiv-Aids Di Kota Medan (Studi Kasus).

Widiaji, B. E. (2015). Konsep Diri, Harapan, dan Proyeksi Hidup Berkeluarga Orang Dengan HIV AIDS (ODHA). 129. 